University of Nebraska - Lincoln

DigitalCommons@University of Nebraska - Lincoln

Nebraska Beef Cattle Reports

Animal Science Department

2014

\title{
Effect of Feeding Distillers Grains and Supplementing with Dietary Antioxidants on Ground Beef Color During Retail Display
}

\author{
Brandy D. Cleveland \\ University of Nebraska-Lincoln \\ Chad G. Bower \\ University of Nebraska-Lincoln, cbower357@gmail.com \\ Amy L. Redfield Redfield \\ University of Nebraska-Lincoln \\ Gary A. Sullivan \\ University of Nebraska-Lincoln, gary.sullivan@unl.edu
}

Follow this and additional works at: https://digitalcommons.unl.edu/animalscinbcr

Part of the Large or Food Animal and Equine Medicine Commons, Meat Science Commons, and the Veterinary Preventive Medicine, Epidemiology, and Public Health Commons

Cleveland, Brandy D.; Bower, Chad G.; Redfield, Amy L. Redfield; and Sullivan, Gary A., "Effect of Feeding Distillers Grains and Supplementing with Dietary Antioxidants on Ground Beef Color During Retail Display" (2014). Nebraska Beef Cattle Reports. 846.

https://digitalcommons.unl.edu/animalscinbcr/846

This Article is brought to you for free and open access by the Animal Science Department at DigitalCommons@University of Nebraska - Lincoln. It has been accepted for inclusion in Nebraska Beef Cattle Reports by an authorized administrator of DigitalCommons@University of Nebraska - Lincoln. 


\section{Effect of Feeding Distillers Grains and Supplementing with Dietary Antioxidants on Ground Beef Color During Retail Display}

Brandy D. Cleveland

Chad G. Bower

Amy L. Redfield

Gary A. Sullivan ${ }^{1,2}$

\section{Summary}

Ground beef patties from cattle fed corn-based diets with no wet distillers grains (control), wet distillers grains (WDGS), WDGS + $1000 \mathrm{IU} / \mathrm{head} / \mathrm{day}$ vitamin $E, W D G S+150$ ppm/head/ day, Ethoxyquin/TBHQ (Agrado Plus, Novus International, St. Louis, Mo.), or WDGS + $500 \mathrm{IU} /$ head/day vitamin $E+$ $150 \mathrm{ppm} / \mathrm{head} /$ day Ethoxyquin/TBHQ during the finishing phase were compared to analyze color stability during retail display. As display time increased, patties from all dietary treatments had greater discoloration and became darker, less red, and more yellow. Therefore, beef patties discolored during retail display, but the rate and degree of discoloration were unaffected by diet or antioxidant supplementation.

\section{Introduction}

Each bushel of corn $(56 \mathrm{lb})$ used in dry-mill ethanol production generates about $17.4 \mathrm{lb}$ of distillers grains available for livestock feed (USDA Economic Research Service). This availability provides an economical feed source for cattle. Consequently, cattle fed distillers grains have an increase in polyunsaturated fatty acids, which may decrease oxidative stability (2009 Nebraska Beef Cattle Report, pp. 107109 and 110-112). The polyunsaturated fatty acids are more easily oxidized and allow off-flavors to develop. In addition, beef from cattle fed distillers grains discolors at greater rate due to oxidation of the muscle pigments. Previous research indicates that dietary antioxidants increase the oxidative stability in fresh, whole muscle meat

Table 1. Visual and instrumental color of ground beef patties.

\begin{tabular}{lccccccc}
\hline & \multicolumn{9}{c}{ Color Analysis } \\
\cline { 2 - 8 } Treatment & \%Dis & $\mathrm{L}^{*}$ & $\mathrm{a}^{*}$ & $\mathrm{~b}^{*}$ & Angle & $\begin{array}{c}\text { Saturation } \\
\text { Index }\end{array}$ & $\begin{array}{c}\mathrm{a}^{*} / \mathrm{b}^{*} \\
\text { ratio }\end{array}$ \\
\hline Corn & 24.66 & 50.21 & 17.54 & 10.37 & 32.65 & 20.55 & 1.66 \\
WDGS & 25.37 & 51.30 & 16.92 & 10.41 & 33.84 & 20.07 & 1.60 \\
WDGS+Vit E & 25.39 & 51.14 & 16.73 & 10.32 & 33.90 & 19.85 & 1.60 \\
WDGS+Agrado & 20.28 & 50.18 & 18.11 & 10.57 & 31.96 & 21.12 & 1.69 \\
WDGS+Vit E+Agrado & 20.98 & 49.73 & 17.82 & 10.39 & 32.12 & 20.80 & 1.69 \\
\hline
\end{tabular}

products. The objective of this trial was to evaluate the effects of vitamin $\mathrm{E}$ and Ethoxyquin/TBHQ (Agrado Plus, Novus International, St. Louis, Mo.) supplementation on ground beef color from cattle fed distillers grains during the finishing phase.

\section{Procedure}

Cattle $(n=100)$ were randomly assigned to one of five finishing diets: corn based diet with no WDGS (control), wet distillers grains (WDGS), WDGS + 1000 IU/head/day vitamin E, WDGS + $150 \mathrm{ppm} /$ head/day Agrado Plus, or WDGS + 500 IU/ head/day vitamin $\mathrm{E}+150 \mathrm{ppm} / \mathrm{head} /$ day Agrado Plus. At the conclusion of the finishing phase, cattle were harvested at commercial abattoir. Forty-eight hours post-harvest, seven USDA Choice clods from each dietary treatment group were collected from the right side of carcasses, vacuum packaged, and shipped to the University of Nebraska-Lincoln Loeffel Meat Laboratory. On day 14, each clod was independently ground and formed into $4 \mathrm{oz}$ patties using a manual, single-patty press. Two patties from each clod were overwrapped with oxygen permeable PVC film and placed under simulated retail display for seven days at $37^{\circ} \mathrm{F}$. During retail display, percent discoloration (\%Dis; 5 person panel; $0 \%=$ no discoloration to $100 \%$ $=$ full discoloration) and objective color $\left(L^{*} a^{*} b^{\star}\right)$ were evaluated for seven days. The $\mathrm{a}^{\star} / \mathrm{b}^{\star}$ ratio, hue angle, and saturation index were then calculated. Data were analyzed by treatment with repeated measures (day) utilizing the PROC MIXED procedures of SAS (SAS Institute, Inc., Cary, N.C.).

\section{Results}

There were no dietary treatment effects for any of the color traits measured $(P>0.39)$ suggesting that diet did not affect the retail shelf life of fresh ground beef. This is in contrast to the increased discoloration rate in cattle finished on modified wet distillers grains from a previous study $(2014 \mathrm{Ne}$ braska Beef Cattle Report, pp. 105-106). As expected, there was a time effect for percent discoloration, $\mathrm{L}^{*}, \mathrm{a}^{*}, \mathrm{~b}^{*}, \mathrm{a}^{*} / \mathrm{b}^{*}$ ratio, hue angle and saturation index $(P<0.0001$ for all). As retail display time increased, patties from all dietary treatments had greater percent discoloration and became darker, less red, and more yellow. Lower values of $\mathrm{a}^{\star} / \mathrm{b}^{\star}$ ratio and saturation and greater values of hue angle are indicators of discoloration, and all were shown over time in the beef patties (Table 1). Regardless of diet, retail display life of beef patties was similar for both instrumental and visual color analysis.

\footnotetext{
${ }^{1}$ Brandy D. Cleveland, graduate student; Chad G. Bower, graduate student; Amy L. Redfield, graduate student; Gary A. Sullivan, assistant professor, University of Nebraska-Lincoln Department of Animal Science, Lincoln, Neb.

${ }^{2}$ This project was funded in part by the University of Nebraska Agricultural Research Division.
} 